to act as treasurer of the fund, and all subscriptions should be addressed to him at the London School of Economics, Houghton Street, Aldwych, W.C.2, England.

\section{Anglo-German Stork Experiments}

THE present experiments on the migration of the stork (Ciconia alba) being carried out in England in conjunction with German ornithologists is evidence of the wider possibilities of international co-operation in field ornithology than have hitherto obtained. Earlier in the spring, eleven storks' eggs from German nests were sent to England and placed in heron nests in Surrey by the Haselmere Educational Museum, as the stork is no longer a British nester, and it was hoped the experiment would indicate whether or not the English-born birds under heron foster-parents would follow the same migration route as German birds. However, only one egg hatched, and after a week the stork chick was accidentally crushed to death by the foster parent. It is hoped to repeat this experiment next spring. In June, a further experiment was made when twenty-three nestling storks from East Prussia were distributed to artificial nests in Scotland, Kent and Surrey where they were hand-fed, and it is hoped that if reared, these birds, which are ringed, will shed further light on migration, and how far inheritance plays a part in it.

Much work on the migration of storks has been carried out on the Continent in recent years. The early experiments at bird-ringing were made by Brugmann in Holland and Mortensen in Denmark last century with storks (NATURE, Sept. 30, 1933), and later research showed that birds nesting east of the River Elbe used an Asia Minor route to the Natal winter quarters and those nesting west of the river a route through Spain and Morocco. Three years ago, young storks born east of the Elbe were ringed and released west of the river, but soon found their way back. The small percentage of stork rings recovered in Africa has lately been shown to be due to the Egyptian natives treasuring them as tokens for fertility, a barren woman who obtained one having worn it and given birth to children, and hence the superstition spread. Skougaarde has reported a stork ringed in Jutland and believed to have lived between thirty and forty years.

\section{Hadrian's Wall}

Excavation of the fort on the Roman Wall at Halton Chesters, near Newcastle-on-Tyne, by the University of Durham Excavation Committee, has made it possible to state definitely for the first time that the building of the wall was completed within a period of five years. A dedicatory tablet on the west gate of the fort has been found, it is stated in a report of the Committee (The Times, July 13), which bears the name of Platorius Nepos, the Governor of Britain in A.D. 122-126. As he also directed the first stages of building, the whole erection was completed within his term of office. The excavation has thrown much light not only on the methods of planning and construction of the fort but also on that of the wall itself. It is evident that the original plan was not always followed. For example, the original ditch fronting the wall runs straight through below the existing fort, one of six, which projects $200 \mathrm{ft}$. north of the wall. The east and west gates of the fort are carried down the entire depth of the filled-in ditch and are built on massive foundations. There is evidence of two considerable reconstructions or enlargements. After the Caledonian invasion, the Emperor Severus rebuilt the fort in about the year A.D. 205, erecting a monumental fore-hall in front of the administrative building. No hall so fine as this, it is stated, has as yet been discovered in Britain, where, in any event, they are rare. It is shown by the foundations to have been $160 \mathrm{ft}$. long by $30 \mathrm{ft}$. broad, with a central entrance spanning the north-to-south street. About a century later the fort was increased in size by an enlargement towards the west behind the shelter of the wall. This structure gave the fort the peculiar L-shaped plan which has long been a puzzle to archæologists.

\section{Meteorology for Airmen in India}

A COPY has been received of a new publication of the India Meteorological Department (M.O.A. Pamphlet 1936) entitled "Meteorological Organisation for Airmen". The purpose of this pamphlet is made clear in the introductory pages by the DirectorGeneral of Observatories, where the relevant part of the organization of the Department is described, together with the procedure to be adopted to obtain weather reports for the different parts of the area with which the Department is concerned; this area extends from the south-eastern half of the Persian Gulf across the whole of Baluchistan, India and Burma. It is admitted that the existing organization for the supply of weather reports and forecasts for such a vast area falls short of the standards recom. mended by the International Convention for Air Navigation, particularly in the south of India, the reason being the size of the area in relation to the permitted financial expenditure on the organization, which is less than what it was formerly in spite of the increased demands of aviation, a fact that has necessitated various reductions, including the closing down of the important forecasting office at Quetta.

ThE different areas covered by the forecasting centres in India are shown on a key map, which indicates also the centres themselves, the different airship bases, the pilot balloon stations from which information about the winds of the upper atmosphere can be obtained, and the aeronautical wireless stations. More precise information about these centres is given in extensive tables, which, together with further tables giving the various weather codes in use in India, occupy the greater part of the fiftyone pages of the pamphlet. Information of the kind provided is of course practically essential to airmen flying in a part of the world subject to very violent disturbances, ranging from tropical hurricanes to duststorms and tornados and other local 